\title{
Detroit Living Amid Ruins
}

\author{
LUIS PANCORBO \\ University of Virginia
}

Public spaces and monuments act as the material representatives of historic memory of traditional cities. There is an international consensus to value, catalog and preservation of these spaces and buildings, both for their heritage, as well as their cultural and historic value. In contrast, certain American urban agglomerations, like Detroit, which has a clear industrial origin, the historic memory of the city is materialized not in its public spaces, which it lacks, but in its productive spaces. Instead of a relatively more normative risk of terrorist attacks to public spaces, these productive spaces risk abandonment, and progressive deterioration. They suffer this fate due to the lack of awareness, both by citizens and institutions, to their importance as carriers of the foundational DNA of these societies. This is leading to their disappearance in the not too distant future.

These productive spaces were initially linked to industrial structures that sometimes reached global relevance. This is the case with the Ford Motor Company. Their industrial philosophy that was able to rename an era of human civilization was of enormous influence in all areas of Western culture. They are the paradigm of this situation.

The city of Detroit is structured around the ruinous remains of this industrial civilization. In these ruins, the memory of the city has been encrypted. However, the patrimonial valuation of this type of monument is far from that enjoyed by traditional monuments in other areas, such as Europe. The lack of appreciation of the industrial ruins of Detroit is due to various factors that are discussed in the article. This attitude follows a historical pattern similar to the Kubler-Ross model in Psychology, including the following phases: denial, contempt, exaltation, and acceptance.

This text exemplifies each of the phases of this pattern using authors such as WG Sebald, Peter Blake, and Camilo Jose Vergara, and artistic movements such as Ruin-Porn, and advocates to achieve the necessary acceptance and integration of these facilities in the urban heritage.

To achieve this last objective, a series of conceptual strategies are proposed that are based on the reformulation of these ruins: de-Urbanization,de-stabilization, de-Industrialization.

\section{INES MARTIN ROBLES}

University of Virginia

\section{UNAVOIDABLE RUINS}

Ruins have been historically one of the recurrent tropes for occidental culture. For instance, Renaissance was, in accordance with many researchers as Andrew Hui, the "birth of the ruin as a distinct category of cultural discourse." ${ }^{1}$ Therefore, for these authors, Renaissance could be renamed as "Ruinnaissance." Although we think this statement is true, many precedents can be pointed out for the aesthetic consideration of ruins. The first can be from Pausanias' literary depiction of ruinous classic temples in his "Description of Greece" of the second century that was the guide for the ruin researchers of the 18th century. Closer to the Renaissance times, we can find the medieval guides to the ruins of Rome or "Mirabilia" of the 12 th century.

Unlike other tropes in art history, ruins don't appear and disappear from the mainstream of aesthetic influence, they are always there, but they receive a different kind of assessment. It can be said that ruins, probably because their ubiquitous presence in our everyday environment, don't have phases of latency or presence in the aesthetic discourse as Aby Warburg states for other artistic features in his theory of "Das Nachbelen Der Antike" (the Survival of Antiquity).

Ruins are always there because their essential material qualities and because they are an unavoidable part of the life cycle of a building. Ruins are by definition buildings, material elements that have lost their use value and therefore assume the only function left for them: being a monument. The first definition of the monument, delivered by Varro in his book "De Lingua Latina" in the 1st Century is:

"Meminisse, to remember, comes from memoria, "memory" since there is once again a movement back to that which has stayed in the mind; this may have been derived from manere "to remain," like manimoria. From the same word comes monere, "remind," because he who remains is just like memory: so are derived monimenta, "memorials," which are in burial places and for that reason are situated along the road. From this use, other things that are written or produced for the sake of memory are called monimenta, "reminders."

This relationship between places and memory makes ruins almost the opposite to the classical arts of memory studied by Frances A. Yates. ${ }^{3}$ Memory is supported in the Art of Memory by imagined places. Memory supports the material 


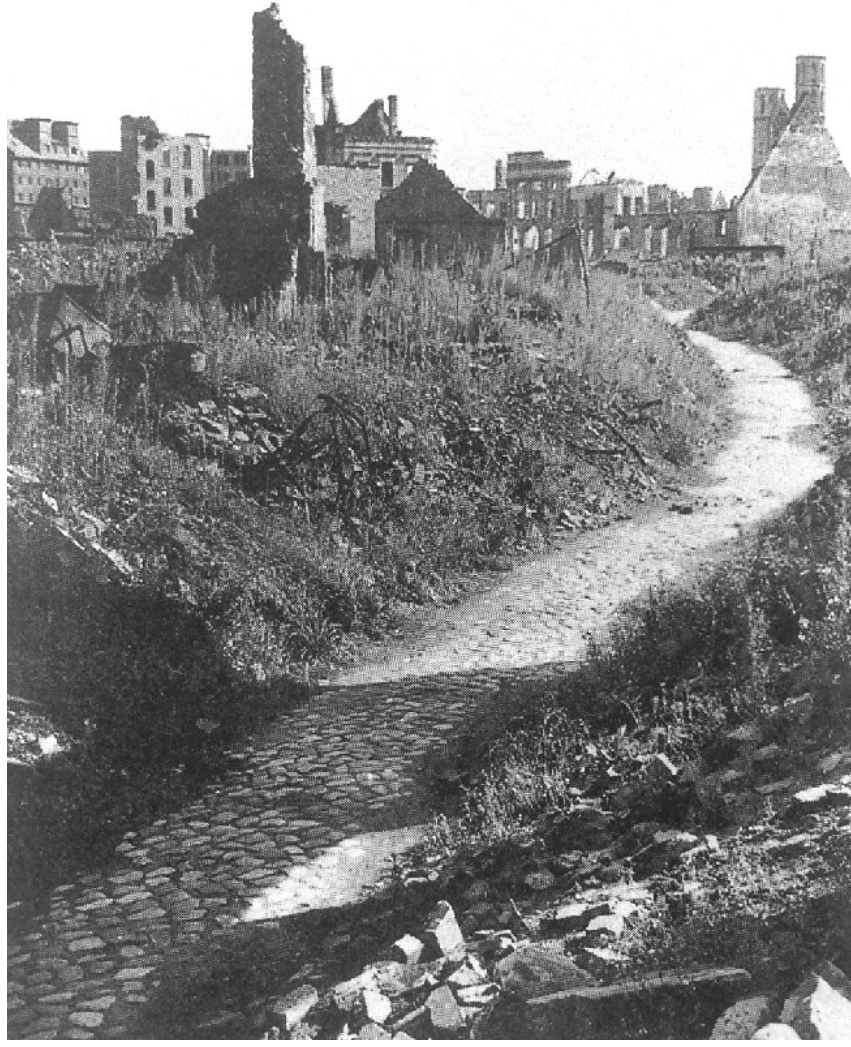

Figure 1: SEBALD, WG . On the Natural History of Destruction. The Modern Library. New York, 2004. Picture of a bombed German city.

places that ruins create, transforming them into monuments. In the following parts of the paper, we will review the different phases of assessment of ruins in history, and then after reviewing the relationship between modernity and ruins, we will center our attention on the city of Detroit, explaining its essential characteristics as a ruined city and analyzing its possible future evolution.

\section{ASSESSMENT CYCLES}

These phases of different reception of ruins follow a cyclic pattern, in which alternative assessment occurs within different cultural environments and periods. This attitude follows a historical pattern similar to the model established for grief by Elisabeth Kübler-Ross in her 1969 book "On Death and Dying," this original model has the phases: Denial, Anger, Bargaining, Depression, and Acceptance

Our model for assessment of ruins include the following phases: Denial, Contempt, Exaltation, and Acceptance. Of course, these phases are not linear and successive, and some of them can coexist in the same space and time.

\section{DENIAL}

The phase of denial of a ruinous environment can be found after every catastrophe affecting cities. The denial of the ruins of Rome occurred after the Visigothic sack of the city in 410 that put an end to classical culture and lead to an obscure era in which the inhabitants of the city lived amid ruins almost without acknowledging their presence. The ruins were considered as almost natural elements, subject to erosion and degradation. These obscure eras finished when ruins of Rome were rediscovered two times; by Early Renaissance and late Renaissance men like Palladio (after the second sack of Rome in 1527). ${ }^{5}$

A brilliant study of this kind of denial phase is in WG Sebald's book: "On the Natural History of Destruction." In this book, Sebald analyzes the social amnesia caused by the bombings and subsequent destruction of the German cities at the end of World War II and its denial in German literature. Quoting Alfred Doblin, who visited the ruins of the cities coming from his America exile:

"People walked down the street and past the dreadful ruins as if nothing had happened, and the town had always looked like that."

Sebald describes this denial of ruins and this naturalization of cities:

"At the end of the war, some of the bomb sites of Cologne had already been transformed by the dense green vegetation growing over them- the roads made their way through this new landscape like peaceful deep-set country lanes."7

There was even a proposal for the "pastoralization" of Germany, delivered by the US Secretary of the Treasury, Henry Morgenthau. In the same mood, the Mirabilia or Medieval Guides to the Ancient ruins of Rome established the relevance of those ruins only as Christian pilgrimage centers. This attitude, that is another more subtle kind of denial, meant the oblivion of those ruins as the memory of a past civilization and drove to their material decay for centuries. ${ }^{8}$

\section{CONTEMPT}

Denial is usually followed by anger and contempt. This attitude toward ruins can be exemplified with the phenomena of "Spolia" of classical ruins. David Karmon in his book "The Ruin of the Eternal City" documented this process of destruction of the classical monuments of Rome. These ruins were sometimes disassembled to use their parts in new constructions. Other times, the old stones were subtracted to be ground and transformed into lime for the new constructions.

Karmon collected several original Papal permits, starting in 1426, issued to lime kiln operators and builders to extract marble from some ancient monuments. Contempt for ruins overlapped with their exaltation and occurred at the starting point for Renaissance. 

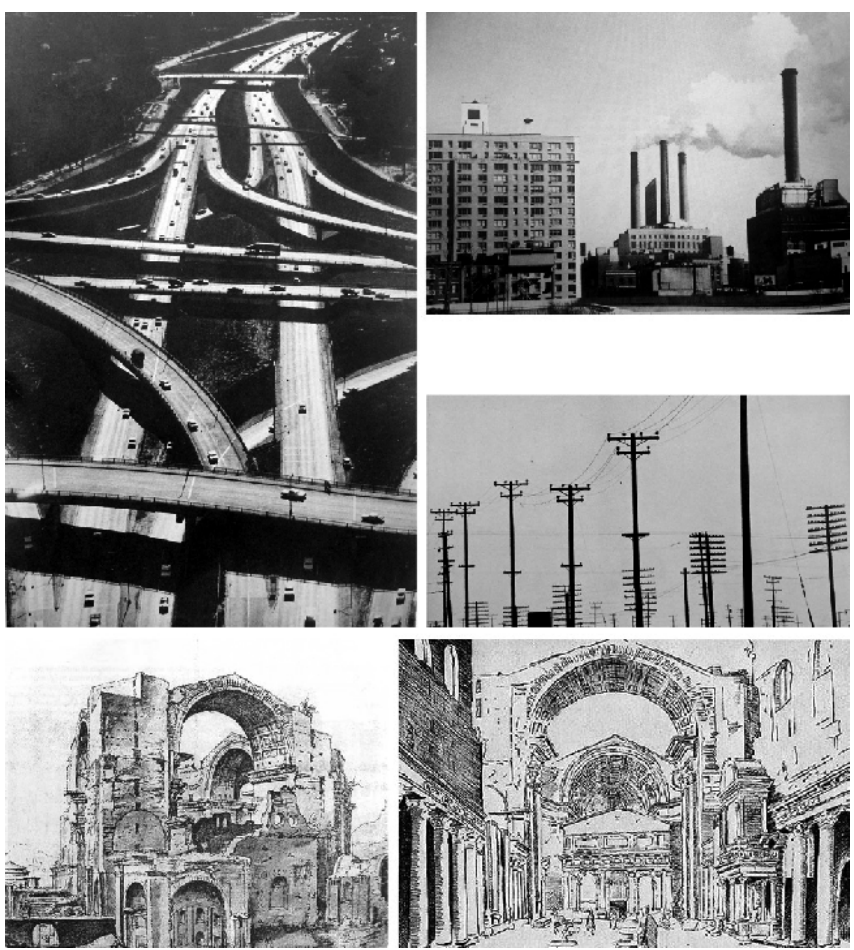

Figure 2: Upper part: Peter Blake. Pictures from "God's Own Junkyard." BLAKE, Peter. God's Own Junkyard. The planned deteroration of America's landscape. Holt, Rinehart and Winston. New York/Chicago/San Francisco, 1964. Lower part: Martin van Heemskerck. drawing of the overlapping destruction of Old Saint Peter and the construction of the New Saint Peter. in Rome. From: SALMON, Frank. Building on Ruins-The rediscovery of Rome and British Architecture. Ashgate Pub. Farnham, 2001

This kind of overlapping of opposite attitudes can be seen graphically in the drawings of Martin van Heemskerck. In his drawings, we can see simultaneously the construction of the New Saint Peter and the destruction of the Old Saint Peter. These illustrations bring up the essential similitude between the stages of construction and ruin of buildings and talk about the possibility of a Creative Destruction in architecture as that described by Max Page in "The Creative Destruction of Manhattan, 1900-1940."10

The strongest manifestation of this contempt for ruins is the 1964 Peter Blake's book “God's Own Junkyard. The planned deterioration of America's Landscape."11 The preface states that the book "is not written in anger. It is written in fury" against the ruination of the American cities and landscapes. Blake reacts against the remains and by-products of the American Industrial Civilization. Infrastructures, industrial buildings, advertisements, and other everyday elements of industrialized America are pointed out as the culprits of the devastation of the American landscape. This process of ruination is illustrated in the book at all scales. The smaller scale of this range is the "micro-ruin" of the urban furniture and pavements along with the disordered accumulation of technical devices on the American urban and sub-urban ambiance: telephone and electric posts, billboards, etc. The second scale of the process of deterioration is exemplified by the presence of junkyards of obsolete technical objects. The urban and landscape scale is illustrated with pictures of transportation infrastructures and industrial facilities as factories. Blake considers all these symptoms of ruination as pathologies that should be eradicated, corrected or at least concealed.

\section{EXALTATION}

The first exaltation of ruins came into place with Renaissance literature. Petrarch and Francesco Colonna are the precursors in the use of ruins as an aesthetic catalyst, followed by painters like Sandro Botticelli and architects like Donato Bramante with his Ruined Temple engraving of 1481. Almost all Renaissance painters have used ruins as background for their paintings.

Ruins came back to the center of the aesthetic debate in the XVIII and XIX Centuries through their exaltation as the best material example of the concept of the sublime.

The list of ruin painters is long: Charles-Louis Clerisseau, Robert Adam, William Chambers, Fragonard, Canaletto, Francois de Nome, Marco Ricci, Pannini, Luigi Rossini, Caspar David Friedrich, Piranesi, Hubert Robert, Joseph Gandy, etc.

Hubert Robert (1733-1808), influenced by his readings of the Compte de Volney, was the first to represent new buildings like the Galleries of the Louvre in ruins, imagining a catastrophic future for them. Piranesi (1720-1778) combines the archaeological precision of his views of Rome with the utopian creations of his "carceri." Piranesi devoted part of his time to the measurement and depiction of many of the ancient edifices, but at the same time worked in their exaltation, creating several fantastic ruinous compositions.

Gandy (1771-1843) was in charge of the graphic depiction of John Soane's buildings. He created simultaneous views of the buildings in their nearly finished state and in a utopian ruinous future.

This romantic view of ruins invaded also the architectural realm, producing several new ruins to complete picturesque landscape designs. The ruinous column of the Désert de Retz is a good example of this trend. This romantic exaltation transcended to contemporary art through a new concept; Ruin-Porn, and a new technique; photography.

Photographers as Camilo Jose Vergara or Marchand \& Meffre show the uncanny beauty of the ruins of industrial cities like Detroit. This movement has raised enormous critical attention. In an article by McLain Clutter, Ruin Porn is praised as:

"Ruin porn elicits a mixture of immediate visual pleasure and lingering ethical guilt. The superficial subjectivities of contemporary culture find scopophilic delight in images of lapsed working-class urbanity emerging through the 

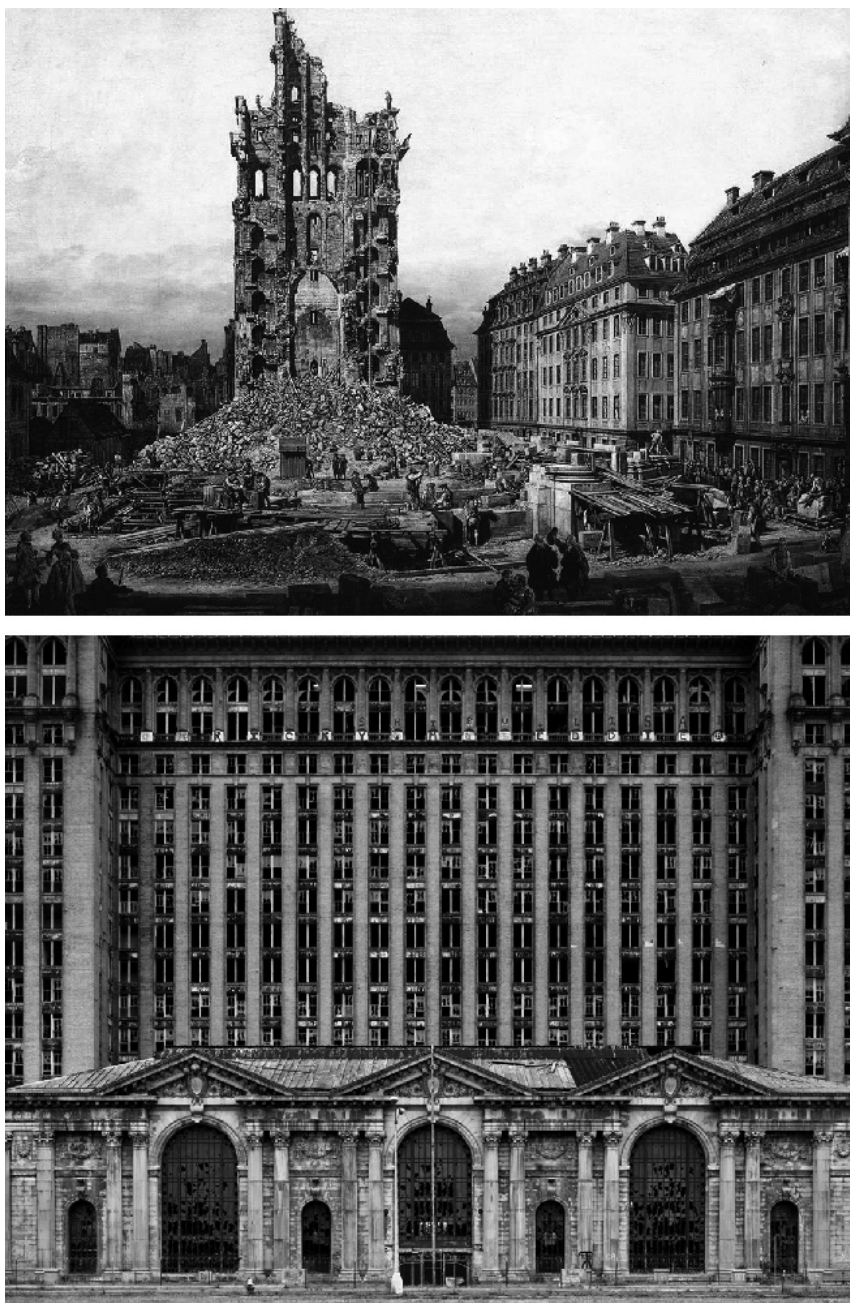

Figure 3: Upper: Bernardo_Bellotto. The Ruins of the Old Kreuzkirche in Dresden. SCHUMACHER, Andreas. Canaletto: Bernardo Bellotto Paints Europe. Hirmer Pub. Munich, 2015. Lower: Detroit's Central Station. MARCHAND, Y; MEFFRE, R. The Ruins of Detroit. Steidl. Göttingen, 2010.

crumbling remains of Fordism. Such remains elicit narratives of bygone urban life that seem so authentic, so real, to the white-collar postmodern audience. Sitting on a couch or in a cubicle, ruin porn drives punctum (to use a term favored by Roland Barthes) through the boredom of perpetual comfort. Meanwhile, the ruins depicted are viewed in the process of being overrun by returning nature, as stone and steel intertwine with encroaching weeds, mold, and wildlife."12

\section{ACCEPTATION}

The acceptation of ruins started with the birth of archaeology and heritage preservation, and the need for an objective depiction of these monuments of the past. The Renaissance treaties like those of Serlio or Palladio, the drawings of Martin van Heemskerck, and the later French and British archaeological campaigns to measure and draw the Roman Antiquities, were the starting points to this new acceptance of ruins.
The central document of this objective revaluation of ruins was Antoine Desgodetz's "The antique buildings of Rome drafted and measured with precision," published in 1682 This book was followed by very relevant others produced by French and British architects like Peyre, De Wailly, MoreauDesproux, Charles Cameron, Robert Woods, James Dawkins, John Bouverie, James Stuart, Nicholas Revett, etc. The same kind of objective and documentary spirit fuels the contemporary work of Hilla and Bernd Becher and their systematic photographs of industrial facilities.

Although ruins are a preeminent trope in several phases of architectural history, they are rarely associated with Modern Architecture. This is probably due to the close relation of ruins with the picturesque and romantic ideals that transform ruins in almost the opposite to the purity, hygiene, and completeness of rationalist architecture. Nevertheless, this view is distorted by our assumptions on what the canonical Modern Movement was. In fact, the beginning of modernism was fueled by a change of paradigm, from classical tradition to new kinds of traditions as vernacular architecture, and especially the industrial vernacular coming from America. Quoting Venturi-Scott Brown-Izenour:

"The architecture of the Modern movement, during its early decades and through a number of its masters, developed a vocabulary of forms based on a variety of industrial models whose conventions and proportions were no less explicit than the Classical orders of the Renaissance. (...) Their factory-like buildings were more than influenced by the industrial vernacular structures of the recent past (...) Their buildings were explicitly adapted from these sources, and largely for their symbolic content, because industrial structures represented, for European architects, the brave new world of science and technology. The architects of the early Modern movement, in discarding the admittedly obsolete symbolism of historical eclecticism, substituted that of the industrial vernacular."13

What the Modern Europeans did not notice is that they were copying obsolete and ruinous objects. Due to the rapid technological changes in production and goods circulation, the factories and grain elevators depicted by Le Corbusier were obsolete by the time of the publication and swiftly becoming ruins.

The acceptation of the role of ruins for modernity came precisely from a series of texts like "Learning from Las Vegas" and "Complexity and Contradiction in Architecture" and Robert Smithson's "A Tour of the Monuments of Passaic, New Jersey" in which the remains of the past American industrial heritage reach a new acceptation.

Specifically, Venturi's books are a reaction to "God's Own Junkyard." Including several of Blake's images, these books are part of a new reflection in which derelict vestiges of industrial objects and facilities start to be tied together with 


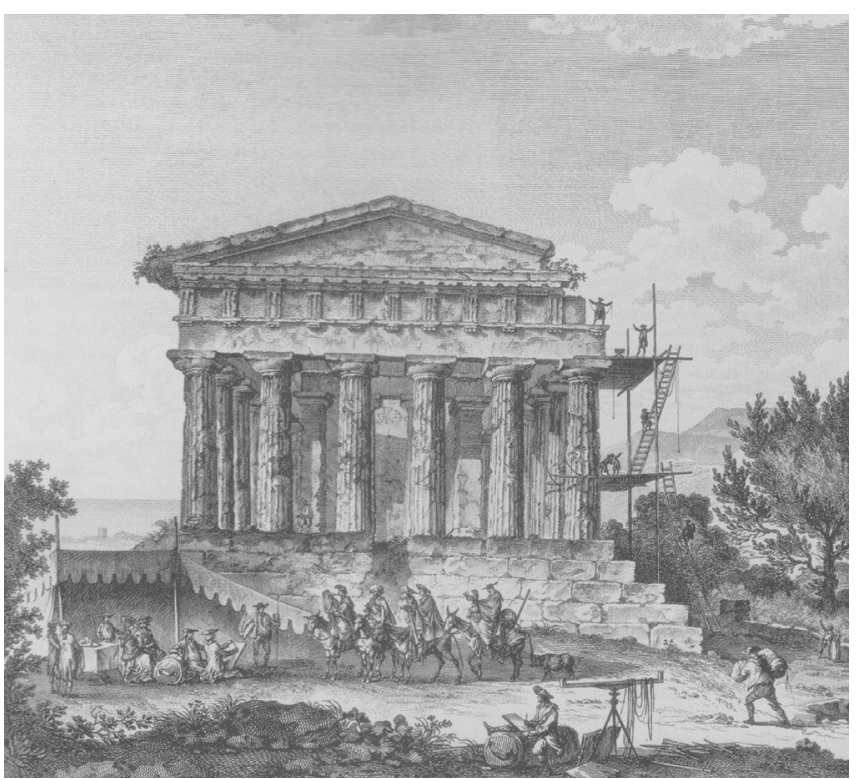

Figure 4: Richard, Abbe de Saint-Non. "Voyage pittoresque de Naples et de Sicilie." Measuring the Temple of Juno in Agrigento. From: SALMON, Frank. Building on Ruins-The rediscovery of Rome and British Architecture. Ashgate Pub. Farnham, 2001

other "ugly and ordinary" elements and accepted as part of the American urban landscape in a continuous process of construction and destruction. Robert Smithson creates the concept of ruins in reverse to try to explain this consistent evolution of the artificial environment:

"That zero panorama seemed to contain ruins in reverse, that is-all the new construction that would eventually be built. This is the opposite of the "romantic ruin" because the buildings don't fall into ruin after they are built but rather rise as ruins before they are built." ${ }^{14}$

Smithson asks in an ironic mood; "Has Passaic replaced Rome as The Eternal City? If certain cities of the world were placed end to end in a straight line according to size, starting with Rome, where would Passaic be in that impossible progression?." ${ }^{15}$ The answer to his question is probably not, but Marchand and Meffre, two of the main voices of Ruin Porn with their book "The Ruins of Detroit" have found a better candidate:

"Detroit, industrial capital of the XXth Century, played a fundamental role shaping the modern world. The logic that created the city also destroyed it. Nowadays, unlike anywhere else, the city's ruins are not isolated details in the urban environment. They have become a natural component of the landscape. Detroit presents all archetypal buildings of an American city in a state of mummification. Its splendid decaying monuments are no less than the Pyramids of Egypt, the Coliseum of Rome, or the Acropolis in Athens, remnants of the passing of a great Empire." 16

\section{DETROIT, MODERNITY IN RUINS}

Detroit is actually the quintessential Modern city and is a city in ruins. In fact, as the Bucharest of Mircea Cartarescu, we believe it is a city designed as a ruin:

"Bucharest was not like other cities that had developed over time replacing shanties and warehouses with large buildings, replacing horse-drawn trams with electric trams. Bucharest had suddenly appeared in ruins, crumbling, with the flaking plaster and the broken noses of the stucco gorgons, with the electric cables hanging over the streets forming melancholy bunches, with a fabulously varied industrial architecture. They had tried to project from the beginning a city more human and more exciting than the Brasilia of concrete and glass. Bucharest had been designed as a great open-air museum, the museum of melancholy and the ruin of all things." ${ }^{17}$

To explain this assumption, we will start with a statement about the origin and evolution of American cities. American cities have an industrial origin. This is even clearer in the Mid-West cities like Detroit. These cities don't settle, like European cities, over a cultural and material palimpsest, including a highly-humanized surrounding landscape. They were directly laid out over the natural environment. They have a mode of settlement in the physical ambiance similar to that of the technological ensembles in Gilbert Simondon's theories. ${ }^{18}$ The city would be the associated milieu that "mediates the relationship between the technical elements and the natural elements within which the Technical Being functions." ${ }^{19}$ The city is no more a cultural issue, but a technical problem that creates what Antoine Picon defines as a "technical landscape." 20

This fact has consequences for the morphology of the city, and for the kind of obsolescence that we can expect from the urban organism. Traditional cities have a high level of resilience, its cycles of decadence and apogee are continuous, and its obsolescence is always incomplete because it raises from the simultaneous satisfaction (not optimization) of an enormous number of parameters. The technical city like Detroit arises, like a technical ensemble, from the optimization of a limited series of functions. This drives this kind of city to a kind of obsolescence similar to that of the technical object: a complete and catastrophic kind of obsolescence.

The obsolescence of the classical cities as Rome produces ruins that can be reused and reclaimed by the city for new functions. The obsolescence of the technical city produces a new kind of ruins. They are not architectonical ruins, but the ruin of an associate milieu whose excessive specialization makes the city unable to adapt to any change. 

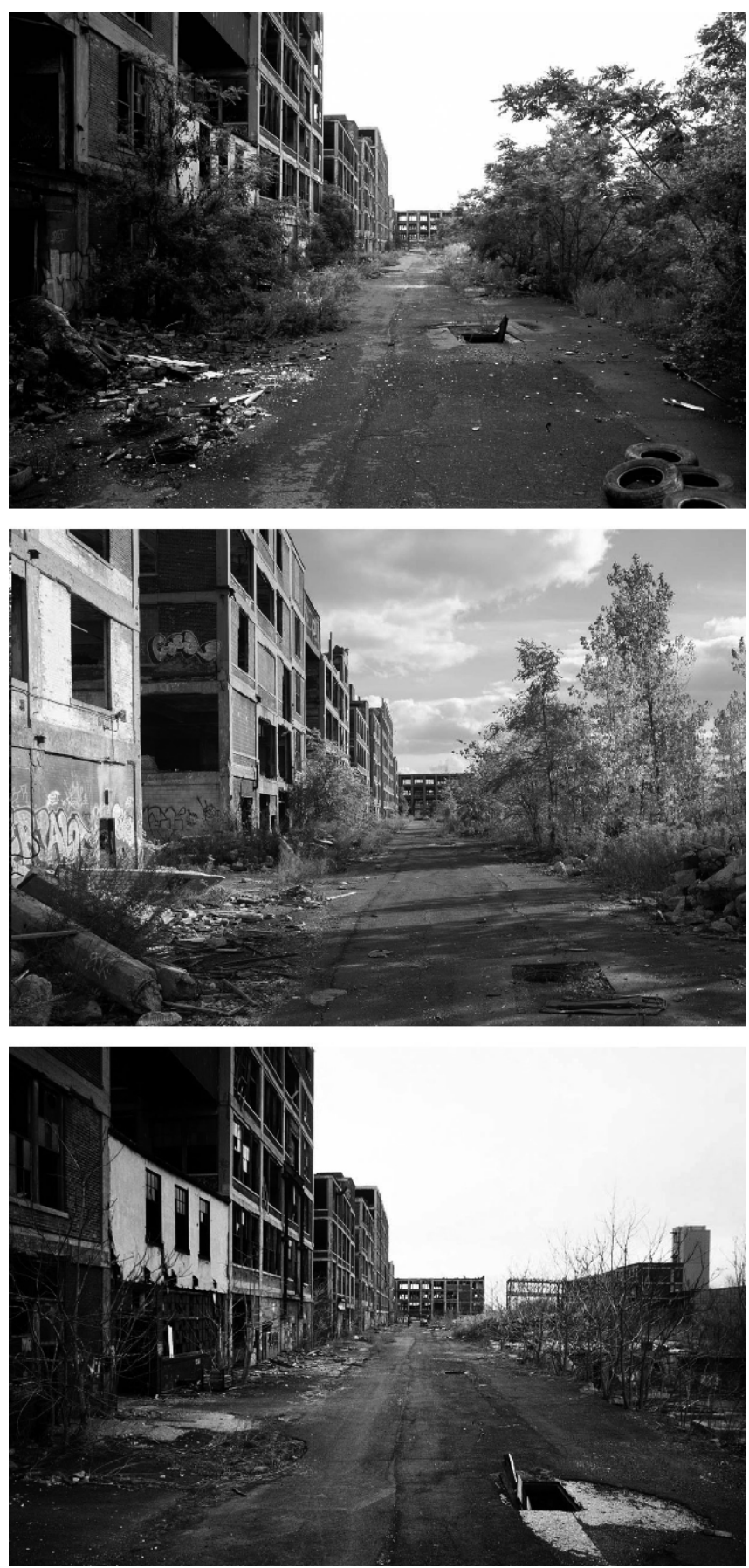

Figure 5: Camilo Jose Vergara. Sequence of pictures of the Packard Plant in Detroit. VERGARA, Camilo J. Detroit Is No Dry Bones: The Eternal City ofthe Industrial Age. Univ. Of Michigan Prss. Ann Arbor, 2016.

Detroit is a giant factory created by the logic of industrial production and circulation. As any other industrial facility, Detroit has in its DNA the seed of its own destruction. For an industrial building, and for the industrial city, "dysfunction is the prelude to ruin." 21

Other morphological features add even more complexity to the obsolescence of Detroit. The scale of the industrial facilities within the city is so big that makes economically impossible their demolition or their repurposing. Factories like the Packard plant are almost cities within the city.

Detroit is a city designed to stress mechanized movement. A solid system of automobile highways and an abandoned railway system interconnects the ruined factories. The industrial buildings of Detroit, and especially those designed by Albert Kahn are as much factories as freight stations. The railroads not only connect every factory but also enter inside every factory. This creates a city that is not an archipelago as stated by Stan Allen but like an interconnected neuronal tissue. The memory of the city is not materialized in its public spaces, which it lacks, but in these productive spaces.

\section{CONCLUSION. LIVING AMID RUINS}

It is clear that Detroit has passed through the stages of denial, contempt, and exaltation. To achieve the necessary acceptance and integration of these facilities in the urban heritage, and due to the structural differences with the classic city, the traditional preservation tools used in Europe become useless in this context. The survival of the industrial city looks doomed to its mutation into a new post-urban type. We propose 3 new conceptual strategies based on the reformulation of these ruins:

\section{DE-URBANIZATION}

The goal is to create supports for new ecosystems, using the material condition of the ruins. These post-industrial and post-urban environments could be refashioned as hybrid techno-biological ecosystems avoiding pastoralism. This idea has some precedents in the perception of ruins of Percy $B$. Shelley and the botanist Richard Deakin. Ruins as biological habitat were first envisioned by Shelley. At the beginning of his "Prometheus Unbound" describes the Baths of Caracalla as a romantic natural landscape, and in some letters insisted in this view of ruins as support for wilderness:

"The perpendicular wall of ruins is woven into steep ravines filled with flowering shrubs whose thick twisted roots are knotted in the rifts of the stones (...) The thick entangled wilderness of myrtle \& bay (..) \& the wild fig \& a thousand nameless plants sown by the wandering winds (forming) a landscape like mountain hills intersected with paths like sheep tracks."22

A more scientific approach to the same idea was used by Deakin who in 1855 cataloged and illustrated more than 420 species of plants growing in the 6 acres of ruins of the Roman Colosseum. ${ }^{23}$

\section{DE-STABILIZATION}

The goal is to create supports of hybrid social activities between the public and the private, using the spatial condition of the ruins. The informal, flexible, and sometimes illegal procedures of the Ruin Porn adepts can help us to understand 
new instrumentalities to approach the use of these abandoned spaces of Detroit. This strategy means a colonization of ruins in a very long period, and by diverse stakeholders. The selective demolition of the building would be part of the required actions. This is more a free colonization strategy than an attempt to find a specific a program for each space. The strategy drives to establish some ground conditions that can stress a number of different activities, creating a frame with rules always subject to negotiation by the new "settlers." The porosity or density of the space would be also decided not a priori but through political action.

\section{DE-INDUSTRIALIZATION}

The goal is to create supports for new urban transportation nodes, reactivating the railroad network that linked these old industrial facilities when they were in use and which is now in a state of ruin. This strategy takes advantage of the high connectivity of the urban nodal structure and uses the former factories as stations in a new transportation network. The stations would become the catalyst for the new public urban activity. We know that factories became stations in Albert Kahn's era, and we know as well that stations are becoming social, commercial, and cultural nodes nowadays. The improvement of the public mobility in the city can be one of the main goals, in an urban environment dominated by private vehicles.

In a city devoid of public space like Detroit, the enormous ruins of the old automobile industry represent the only feasible instrument for the articulation of spaces at the urban scale. The loss of these structures supposes an irreparable damage, not only for the preservation of the memory of the city but also for its possibilities of future evolution.

\section{ENDNOTES}

1. Hui, Andrew. The Poetics of Ruins Renaissance Literature. Fordham University Hui, Andrew. The Poetics of Ruin
Press. New York, 2006. P 177.

2. Ibid.

3. Yates, Frances A. The Art of Memory. Routledge. Oxford-New York, 2010.

4. Kubler-Ross, Elisabeth. On Death and Dying: What the Dying Can Teach Doctors, Nurses, Clergy and Their Own Families. Macmillan Publishing Co., Inc. Doctors, Nurses,

5. See the chronicles of the post-sack Rome in: GOUWENS, Kenneth. Remembering the Renaissance. Brill. Leiden, the Netherlands, 1998.

6. Sebald, W.G. On the Natural History of Destruction. The Modern Library, New York, 2004. P 5.

7. Ibid. $\mathrm{p} 39$

8. See for instance: Mirabilia Urbis Romae and Narratio de Mirabilibus Urbis Romae, both of the XII Century or the older Itinerarium Urbis Romae of the early ninth century.

9. Karmon, David. The Ruin of the Eternal City: Antiquity and Preservation in Renaissance Rome. Oxford University Press. Oxford, 2011.

10. Based in the theories of the economist Joseph Schumpeter. PAGE, Max. The Creative Destruction of Manhattan, 1900-1940. The University of Chicago Press. Chicago, 2002
11. Blake, Peter. God's Own Junkyard. The planned deteroration of America's landscape. Holt, Rinehart and Winston. New York/Chicago/San Francisco, 1964.

12. Clutter, McLain. "Notes on Ruin Porn." http://www.averyreview.com/ issues/18/notes-on-ruin-porn

13. Venturi, Robert: SCOTT BROWN, Denise: IZENOUR, Steven. Learning from Las Vegas. The MIT Press. Cambridge, 1991. P135.

14. Smithson, Robert. "The Monuments of Passaic," Artforum, December 1967, p.52-57

15. Ibid

16. http://www.marchandmeffre.com/detroit

17. Cartarescu, Mircea. Solenoide. Impedimenta. Madrid, 2017. P 30.

18. Simondon, Gilbert. On the Mode of Existence of Technical Objects. University Of Minnesota Press. Minneapolis, 2017.

19. Ibid. p78

20. Picon, Antoine. "Anxious Landscapes. From the Ruin to Rust." Grey Room 01. Autumn, 2000. P 64-83.

21. Harbison, Robert. Ruins and Fragments: Tales of Loss and Rediscovery. Reaktion Books. London, 2015. p26.

22. Woodward, Christopher. In Ruins: A Journey Through History, Art, and Literature. Vintage. New York, 2002. P 67.

23. Deakin described several different microclimates inside the ruins. Some of the species were so exotic in Europe than they were presumably transported on the fur of the animals used for the gladiator games. Deakin's work has some precedents and followers: Panaroli in 1643, Sebastiani in 1815, Fiorini Mazzanti in 1874, and Anzalone in 1951. See. CANEVA, Giulia. Amphitheatrum 